\title{
New and noteworthy records of coprophilous species of Coniochaeta and Sordaria (Sordariomycetes, Ascomycota) from Ukraine
}

\author{
Yulia I. LYTVYNENKOํㅜ, Vera P. HAYOVA² \\ ${ }^{1}$ A.S. Makarenko Sumy State Pedagogical University \\ 87 Romenska Str., Sumy 40002, Ukraine \\ lytvynenko2014@gmail.com \\ ${ }^{2}$ M.G. Kholodny Institute of Botany, National Academy of Sciences of Ukraine \\ 2 Tereshchenkivska Str., Kyiv 01004, Ukraine \\ v.hayova@gmail.com
}

Lytvynenko Yu.I., Hayova V.P. New and noteworthy records of coprophilous species of Coniochaeta and Sordaria (Sordariomycetes, Ascomycota) from Ukraine. Ukr. Bot. J., 2018, 75(6): 538-551.

Abstract. The article reports new data on the occurrence of five coprophilous species of the genera Coniochaeta and Sordaria in Ukraine. These fungi represent a large group of coprophilous Sordariomycetes. Unlike fimicolous discomycetes, this group of fungi is poorly studied in Ukraine. The dung samples were collected on Tendra Island in the Black Sea (Kherson Region), and in the north-east of the country (Sumy Region). All specimens were obtained by incubating of the dung samples in moist chambers. Three species, Coniochaeta leucoplaca, C. vagans, and Sordaria minima are newly reported in Ukraine; the latter is for the first time recorded in Eastern Europe. For other two species, Sordaria alcina and S. humana, these are the second records in the country. For all species, descriptions of the Ukrainian specimens on various types of dung are provided and compared to original descriptions. Based on the collected specimens, distinctive morphological characters of the species are described in detail. All species are illustrated by micrographs obtained using light and scanning electron microscopy. For each specimen, its locality, substrate, and collection date are indicated. In addition to morphological characters, ecological peculiarities and data on general distribution of these species are briefly discussed.

Keywords. Coniochaeta leucoplaca, Coniochaeta vagans, Sordaria alcina, Sordaria humana, Sordaria minima, coprophilous fungi, dung, distribution

\section{Introduction}

Coprophilous fungi, an important component of herbivore dung, are actively involved in decomposition of organic matter in the remains of ingested vegetation. Although fungal communities on dung include representatives of various taxonomic groups, members of the class Sordariomycetes (Ascomycota) possess the highest diversity. In Ukraine, however, perithecioid fungi on dung, despite their ubiquity and dominance on these substrata, until recently remained relatively unexplored, in contrast to coprophilous discomycetes. Only a few species of this group were recorded more than a hundred years ago (Krupa, 1888; Bobjak, 1907; Namyslowski, 1910, 1914). The first list of coprophilous fungi in Ukraine (Milovtsova, 1937) comprised ten species of pyrenomycetes found on dung. In the 2000s, occasional finds of these fungi were made during mycological observations in several nature reserves

(c) Yu.I. LYTVYNENKO, V.P. HAYOVA, 2018 and national nature parks of the country (Dudka et al., 2004, 2009a, b; Hayova, 2005; Akulov et al., 2010). Recent special studies on coprophilous ascomycetes (Golubtsova, 2008; Golubtsova et al., 2010) added eight new records for Ukraine.

This article reports five species of coprophilous fungi of the genera Coniochaeta (Sacc.) Cooke and Sordaria Ces. \& De Not., three previously unregistered in Ukraine species and two which are the second records for the country.

Coniochaeta (Coniochaetaceae, Coniochaetales) is a cosmopolitan genus including lignicolous, terricolous and coprophilous species. The genus is characterized by small non-stromatic perithecioid ascomata bearing dark stiff setae clustered around the neck, or sometimes also scattered on the venter. Coniochaeta species have non-amyloid, unitunicate, short-stalked, cylindric asci and dark brown, one-celled, discoid ascospores with a germination slit along the narrow side and evanescent hyaline sheath surrounding ascospores. According to 
various data, the genus Coniochaeta comprises from 54 (Asgari et al., 2007) to 65 species (Kirk et al., 2008) and only $13-19 \%$ of them are obligate coprophils (Mahoney, LaFavre, 1981; Asgari et al., 2007). These coprophilous species usually appear only on dung incubated for a long time (Bell, 2005). In Ukraine, three lignicolous species of Coniochaeta were recorded so far (Fungi..., 1996; Dudka et al., 2004, 2009a) and a single fimicolous species, C. scatigena (Golubtsova, 2008); the latter one, which is widespread on herbivore dung, was reported on hare pellets.

Sordaria (Sordariaceae, Sordariales) is one of the most widespread and frequently encountered genera among coprophilous ascomycetes. Most species of Sordaria are coprophiles, only few have been occasionally isolated from soil, seeds, plant debris and living plants (Doveri, 2004; Prokhorov, Armenskaya, 2003). The genus accommodates fungi with superficial or semi-immersed perithecioid ascomata, glabrous or covered with sparse hyphoid hairs; non-amyloid asci with a well developed apical apparatus; dark brown, one-celled, more or less ellipsoidal, ovoid or subglobose ascospores with a basal germ pore and often a gelatinous sheath. Lundquist (1972) accepted 16 species of Sordaria; Guarro \& von Arx (1987) and Doveri (2004) provided each a key to 18 and 14 species, respectively; Kirk et al. (2008) referred to 12 species of the genus. In Ukraine, six species of Sordaria are currently known. Sordaria macrospora Auersw. and S. superba De Not. were found on herbivore dung (Smitskaya et al., 1986; Dudka et al., 2009a, b; Akulov et al., 2010; Golubtsova et al., 2010), S. fimicola (Roberge ex Desm.) Ces. et De Not. - on animal dung, on soil and beet (Beta sp.) seeds (Milovtsova, 1937; Smitskaya et al., 1986; Dzhagan et al., 2008; Akulov et al., 2010; Golubtsova et al., 2010) and S. conoidea Cailleux - on hare pellets (Shlakhter, 2014); other two species, S. alcina N. Lundq. and S. humana (Fuckel) G. Winter, were briefly reported once by the first author but not described in detail (Lytvynenko, Stepanovska, 2014).

\section{Materials and methods}

Specimens of the species listed below were collected on dung samples of the following domesticated and wild herbivorous animals: cow (Bos taurus L.), elk (Alces alces L.), hare (Lepus europaeus Pall.), horse (Equus caballus L.), rabbit (Oryctolagus cuniculus L.), roe deer (Capreolus capreolus L.), sheep (Ovis aries L.), and wild boar (Sus scrofa L.). The dung samples were collected during mycological surveys on Tendra Island, a spit in the Black Sea, within the Black Sea Biosphere Reserve (Kherson Region), and in the north-east of the country (Sumy Region). All specimens were obtained by incubating of the dung samples in moist chambers at room temperature $\left(18-20{ }^{\circ} \mathrm{C}\right)$ in natural light for 5 to 30 days, depending on fungal growth and development of ascomata.

Micromorphological characteristics were examined by light microscopy under a stereomicroscope MBS-10 (Russia) and dissecting microscope XSM40 (China). Dimensions of microstructures were measured using Tsview7 modular software (Fuzhou, China). Photomicrographs were taken with $3.0 \mathrm{mp}$ Digital Microscope Camera (Fuzhou, China). Asci and ascospores mounted in tap water were examined at magnifications up to $600 \times$. Spore statistics included length and width (for Coniochaeta spp., width in frontal and side view) on a minimum of 20 samples from each collection. The quotient between spore length and width $(\mathrm{Q})$, as well as the average quotient $\left(\mathrm{Q}_{\mathrm{av}}\right)$, was calculated. The amyloid apical apparatus and walls of the asci were determined by treating with Meltzer's reagent. Aqueous Cotton Blue was used for staining hyaline gelatinous sheaths. For scanning electron microscopy, samples were coated with an ultrathin coating of gold by ion beam sputtering unit JFC-1100. Images were obtained by a scanning electron microscope JEOL JSM-6060 LA (Japan).

The specimens are deposited at the Mycological Herbarium of the M.G. Kholodny Institute of Botany, National Academy of Sciences of Ukraine (KW-M). Taxonomic arrangement, species and authors names are provided according to Index Fungorum online database (http://www.indexfungorum.org/).

\section{Results and discussion}

Taxonomic descriptions of five species of Coniochaeta and Sordaria based on the Ukrainian collections are provided below. Their morphological characters are described in detail and illustrated by micrographs obtained using light and scanning electron microscopy. All examined specimens are listed following the description of each species. For each specimen, its substrate, locality, and collection date are indicated. Ecological peculiarities and data on general distribution of the species are briefly discussed.

Coniochaeta leucoplaca (Sacc.) Cain, Univ. Toronto Stud. Biol. Ser. 38: 61. 1934. ESphaeria leucoplaca Berk. \& Ravenel in Berkeley, Grevillea 4(32): 143 (replaced synonym). 1876. = Sordaria microspora W.Phillips 
\& Plowr., Grevillea 6(37): 28. 1877. 三 Hypocopra leucoplaca Sacc., Syll. Fung. 1: 244. 1882 (basyonym). = Hypocopra microspora (W.Phillips \& Plowr.) Sacc., Syll. Fung. 1: 241. 1882. $\equiv$ Sordaria leucoplaca (Berk. \& Ravenel) Ellis \& Everh., North Amer. Pyren.: 127. 1892. 三Fimetaria leucoplaca (Berk. \& Ravenel) Griffiths \& Seaver, North Amer. Flora 3(1): 68.1910 (Fig. 1, $a-f$ ).

Description of Ukrainian collection. Ascomata perithecioid, scattered, immersed or semi-immersed, dark-brown, subglobose, 290-380 × 220-315 $\mu \mathrm{m}$; neck blackish, subcylindrical, 55-67 × 46-58 $\mu \mathrm{m}$, covered with thick setae. Peridium thick, layered, made up of thick-walled, dark-brown cells. Setae dense at the perithecial neck, 24-40 × 3-4 $\mu \mathrm{m}$, straight, darkbrown, not septate, thick-walled, pointed at the apex. Asci eight-spored, cylindrical, with a short stipe, 87$95 \times 7.7-8.5 \mu \mathrm{m}$; unitunicate, slightly narrowed and flattened at the apex, non-amyloid; apical apparatus well developed and easily observable. Ascospores uniseriate, one-celled, smooth, thick-walled, dark-brown, 7.5$8.5 \times 5.2-6.5 \times 3.9-4.5 \mu \mathrm{m}$, broadly ellipsoidal in frontal view $\left(\mathrm{Q}=1.26-1.53, \mathrm{Q}_{\mathrm{av}}=1.34\right)$, narrowly ellipsoidal in side view $\left(\mathrm{Q}=1.95-2.12, \mathrm{Q}_{\mathrm{av}}=2.05\right)$; germ slit runs around the whole circumference; gelatinous sheath hyaline, 1.7-2.2 $\mu \mathrm{m}$ wide. Paraphyses abundant, hyaline, cylindric-filiform, septate, longer than the asci.

Examined material. Sumy Region, Seredyna-Buda District, vicinity of Vasylivka village, DesnianskoStarohutsky National Nature Park, pine forest, quarter 92, 52 $32^{\prime} \mathrm{N}, 33^{\circ} 75^{\prime} \mathrm{E}$, roe deer dung, 20 September 2016, leg./det. Yu.I. Lytvynenko (KW-M70955).

General distribution. Europe: Bulgaria, Germany, Iceland, Italy, Netherlands, Norway, Russia, Spain, Sweden, Ukraine, UK. Asia: India, Japan, Sri Lanka, Taiwan. Australasia: Australia, New Zealand. North America: Canada, USA. South America: Chile, Falkland Islands, Peru.

Notes. Coniochaeta leucoplaca is a widespread, almost cosmopolitan fungus occurring on dung of numerous species of herbivorous animals and birds. Until recently, taxonomic status of $C$. leucoplaca remained uncertain. Checa et al. (1988) considered it conspecific with $C$. velutina originally described as lignicolous species (Munk, 1957) but later also recorded on dung and soil (Taylor, 1970). Differences between these two species in their habitat (coprophilous vs. lignicolous or terrestrial) and ascospore size 7-9 $\times 6-$ $8 \times 5-6 \mu \mathrm{m}$ in C. leucoplaca (Cain, 1934) and 6-8 $\times 4$ $6 \times 3-4 \mu \mathrm{m}$ in $C$. velutina (Munk, 1957) were regarded by Checa et al. (1988) as insignificant. However, the proposed synonymy was not accepted (Doveri, 2004; Bell, 2005; Asgari et al., 2007). Doveri (2004), following Lundqvist (pers. comm.), emphasized two distinctive morphological characters, ascospore shape and extent of the germ slit. In C. leucoplaca, ascospores are more flattened and a germ slit going all the way around the spore in contrast to one-sided germ slit common in spores of non-coprophilous species. In addition to ascospore morphology, Asgari et al. (2007) took into account anamorphs and distinguished these two species mainly by non-guttulate ascospores, Phialophora-like anamorph in C. leucoplaca and ascospores with 1-2 guttules, Lecythophora anamorph in C. velutina. In order to clarify the taxonomic status of $C$. leucoplaca and $C$. velutina, Chang \& Wang (2011) examined type materials and fresh Taiwanese collections of both species. It was demonstrated that Coniochaeta leucoplaca mainly differs from $C$. velutina by larger and strongly flattened dark-brown ascospores as well as apical part of perithecium covered with pointed setae. Furthermore, morphological distinction between these species was supported by phylogenetic analysis of Coniochaeta species constructed with large subunit ribosomal DNA (LSU $r$ DNA) sequences. Based on the integrated data, Chang \& Wang (2011) regarded C. leucoplaca and $C$. velutina as separate species.

In our observations, ascospores in $C$. leucoplaca are conspiciously flattened (Fig. $1, c, h$ ); those in side view exhibit germ slits extending the full length (Fig. 1, $g, h)$, otherwise ascospores are smooth under SEM (Fig. 1, g). Apical parts of perithecia are usually covered with straight pointed setae (Fig. 1, $b, f$ ); rarely the necks apparently seem almost glabrous (Fig. 1, $a$ ) as reported by Doveri (2004). However, more frequently quite stiff setae cover not only apical but all superficial part of ascomata which is particularly well seen under SEM (Fig. 1, e, f). According to Doveri (2004), Lundqvist also observed that superficial, or not entirely immersed, perithecia may be covered by thick setae not only around the neck but all over and considered this phenomenon as an example of morphological variability of Coniochaeta species. In some ascomata a mouth of the ostiole is seen as a round opening (Fig. 1,f) while in others it is covered with ascospores exuded as a globose mass (Fig. 1,e). In Ukrainian specimen, ascospores are slightly smaller than those indicated for $C$. leucoplaca by other authors (Doveri, 2004; Bell, 2005; Asgari et al., 2007; Chang \& Wang, 2011); in particular, their height and width fall within lower limit of size range. Otherwise, all 

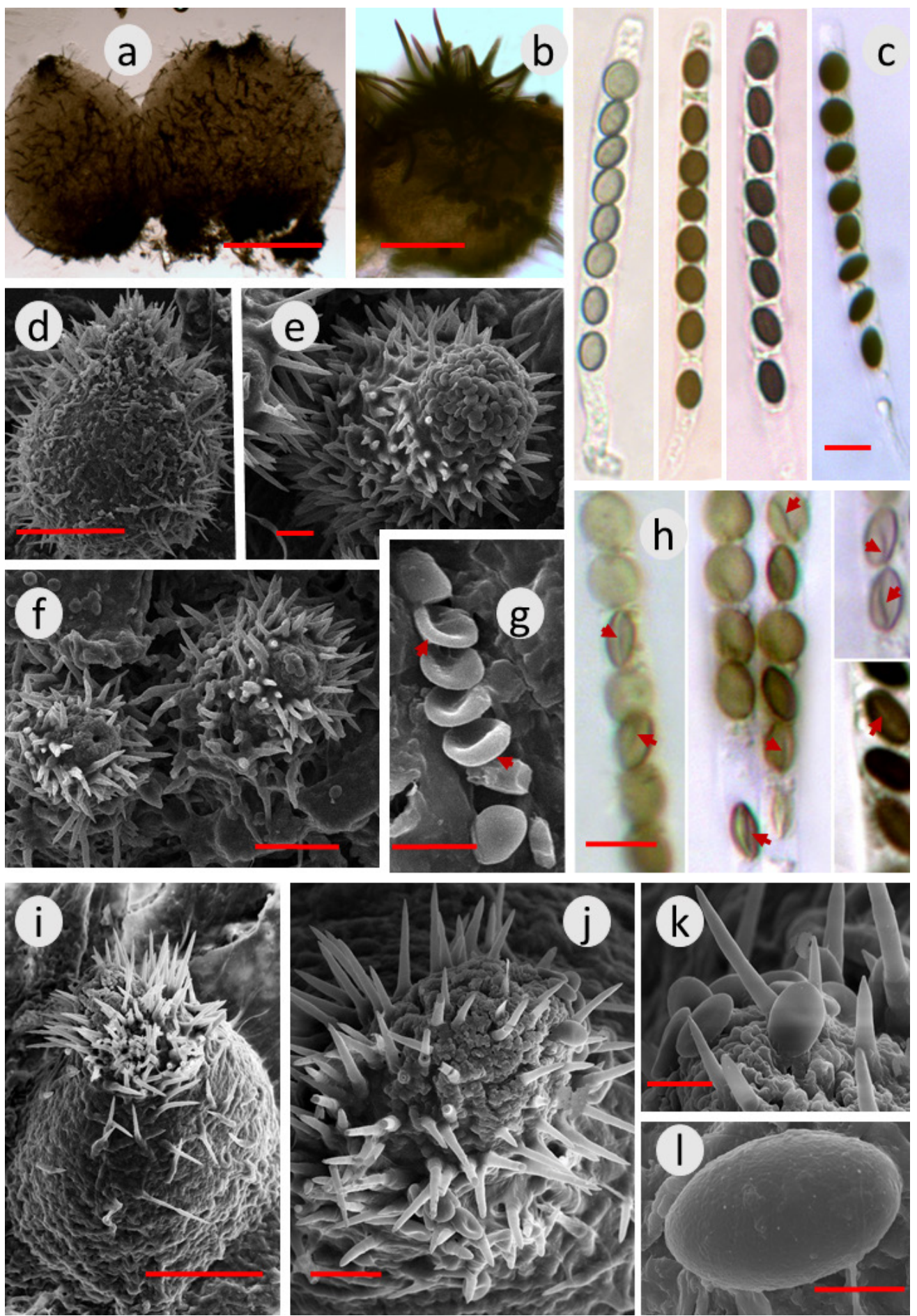

Fig. 1. Coniochaeta leucoplaca (KW-M70955): $a, b$ - squashed ascomata; $c$ - asci with ascospores in different stages of maturity; $d$ - ascoma seen by SEM; $e$ - perithecial neck with setae and ascospores seen by SEM; $f$ - necks with ostioles seen by SEM; $g$ - ascospores with germ slits (arrows) seen by SEM; $h$ - ascospores in different stages of maturity showing germ slits (arrows). Coniochaeta vagans (KW-M50613): $i$ - ascoma seen by SEM; $j$ - perithecial neck with setae seen by SEM; $k$ - setae and ascospores around the ostiole seen by SEM; $l$ - ascospore seen by SEM.

Scale bars: $a, b, d, i-100 \mu \mathrm{m} ; c, h, g, k-10 \mu \mathrm{m} ; e, j-20 \mu \mathrm{m} ; f-50 \mu \mathrm{m}, l-5 \mu \mathrm{m}$

Укр. бот. журн., 2018, 75(6) 
morphological characters fit well the description of C. leucoplaca.

Coniochaeta leucoplaca is new for Ukraine. A close but distinct lignicolous species, $C$. velutina, was recorded in the country in two localities on woody substrates (Fungi..., 1996; unpublished data).

Coniochaeta vagans (Carestia \& De Not.) N. Lundq., Publ. Herb., Univ. Uppsala 8: 9. 1981. 三 Sordaria vagans Carestia \& De Not. in De Not., Comment. Soc. Crittog. Ital. 2(2): 479-480. 1865 (basyonym). $\equiv$ Hypocopra vagans (Carestia \& De Not.) Sacc., Syll. Fung. 1: 241. 1882. = Sordaria discospora Auersw. ex Niessl, Verh. Nat. Ver. Brünn 10: 192. 1872. = Hypocopra discospora (Auersw. ex Niessl) Fuckel, Jb. Nassau. Ver. Naturk. 27-28: 43. 1873 [1873-74]. = Coniochaeta discospora (Auersw. ex Niessl) Cain, Univ. Toronto Studies Biol. Ser. 38: 62.1934 (Fig. 1, $i-l$; Fig. 2)

Description of Ukrainian collections. Ascomata perithecioid, scattered, immersed, dark brown, subglobose to pyriform, $330-400 \times 230-250 \mu \mathrm{m}$, covered with sparse hyphoid hairs; neck blackish, subcylindrical, $69-86 \times 56-67 \mu \mathrm{m}$, covered with thick setae. Peridium thick, layered, made up of thick-walled, pale brown cells. Setae very dense at the perithecial neck, 24-40 × 3-4 $\mu \mathrm{m}$, straight, dark brown, aseptate, thick-walled, pointed at the apex. Asci eight-spored, infrequently six- or four-spored, cylindrical, with a short stipe, $37.3-142.7 \times 12.4-13.5 \mu \mathrm{m}$; unitunicate, slightly narrowed and flattened at the apex, nonamyloid. Ascospores uniseriate, one-celled, smooth, thick-walled, dark-brown, 13.9-17.4 × (8.3-) 9.3-10.9 $\times 6.4-9.0 \mu \mathrm{m}$, broadly ellipsoidal in frontal view $(\mathrm{Q}=$ $\left.1.45-1.59, \mathrm{Q}_{\mathrm{av}}=1.53\right)$, narrowly ellipsoidal in side view $\left(\mathrm{Q}=1.95-2.12, \mathrm{Q}_{\mathrm{av}}=2.05\right)$; germ slit runs around the whole circumference; gelatinous sheath hyaline, 1.5$2.6 \mu \mathrm{m}$ wide. Paraphyses abundant, hyaline, cylindricfiliform, septate, longer than the asci.

Examined material. Kherson Region. Hola Prystan District, Black Sea Biosphere Reserve, Tendra Island, middle part, steppe areas, $46^{\circ} 14^{\prime} \mathrm{N}, 31^{\circ} 35^{\prime} \mathrm{E}$, horse dung, 24 May 2007 (KW-M50645); Tendra Island, Bili Kuchuhury Cape, $46^{\circ} 14^{\prime} \mathrm{N}, 31^{\circ} 38^{\prime} \mathrm{E}$, cow dung, 25 May 2007 (KW-M50643); Tendra Island, near Tendra lighthouse, $46^{\circ} 19^{\prime} \mathrm{N}, 31^{\circ} 31^{\prime} \mathrm{E}$, horse dung, 26 May 2007 (KW-M50613), leg. V.P. Hayova, det. Yu.I. Lytvynenko. Sumy Region. Okhtyrka District, vicinity of Huhra village, Hetmanskyi National Nature Park, forest edge, $50^{\circ} 12^{\prime} \mathrm{N}, 34^{\circ} 48^{\prime} \mathrm{E}$, sheep dung, 20 September 2016; Seredyna-Buda District, vicinity of Ochkyne village, Desniansko-Starohutsky National Nature Park, pine forest, $52^{\circ} 13^{\prime} \mathrm{N}, 33^{\circ} 22^{\prime} \mathrm{E}$, elk dung, 07 August 2008 (KW-M70960), leg./det. Yu.I. Lytvynenko.

General distribution. Europe: Bulgaria, Denmark, France, Germany, Hungary, Iceland, Italy, Russia, Spain, Sweden, Ukraine, UK. Africa: Kenya. Australasia: Australia, New Zealand. North America: Canada, USA. South America: Chile, Falkland Islands, Uruguay.

Notes. This obligatory coprophilous species appears in literature under two synonymic names: $C$. discospora (Fakirova, 1969; Prokhorov, Armenskaya, 2001; Bell, 2005) and C. vagans (Doveri, 2004; Asgari et al., 2007; Heine, Welt, 2008). Moreover, some authors (Moravec, 1968; Hawksworth, Yip, 1981; Mahoney, LaFavre, 1981; Checa et al., 1988; Watling, Richardson, 2010) do not recognize $C$. vagans as a separate species and treat it rather as a synonym of $C$. ligniaria. In that case the latter, which is known to occur on woody substrates, is considered as a species able to colonize both decaying wood and herbivorous dung. In external appearance, as stated by Watling \& Richardson (2010), "it is difficult to see any differences between the material on wood and that on dung". However, as already mentioned above, Doveri (2004) and, subsequently, Chang \& Wang (2011) regarded morphology of ascospore germ slit as a reliable character to distinguish both coprophilous and noncoprophilous species of Coniochaeta. Thus, C. vagans is characterized by ascospores with a germ slit extending the full length (Doveri, 2004) while ascospores of C. ligniaria possess a laterally one-sided germ slit. Furthermore, $C$. vagans differs from $C$. ligniaria by ascospore width which does not overlap. In the former species, spore width in frontal view mostly does not exceed $11 \mu \mathrm{m}$, while in the latter one ascospores are usually wider than $11 \mu \mathrm{m}$ (Asgari et al., 2007).

In our observations, ascospores have a germ slit extending over the entire length of the spore (Fig. 2, d) and do not exceed $11 \mu \mathrm{m}$ in width in face view. These morphological characters as well as ecological characteristics of our collections fit the diagnosis of C. vagans (Doveri, 2004; Bell, 2005; Asgari et al., 2007; Chang, Wang, 2011). Additionally, in our specimens asci are mostly eight-spored; however, occasionally we observed six- or even four-spored asci, with clearly visible two, or respectively, four degenerated ascospores (Fig. 2, $k-p$ ). The tips of the asci are truncate, with a distinct apical structure (Fig. 2, $e, i$ ).

Coniochaeta vagans is reported for the first time in Ukraine. A similar but independent lignicolous species, C. ligniaria, is known in the country from several 

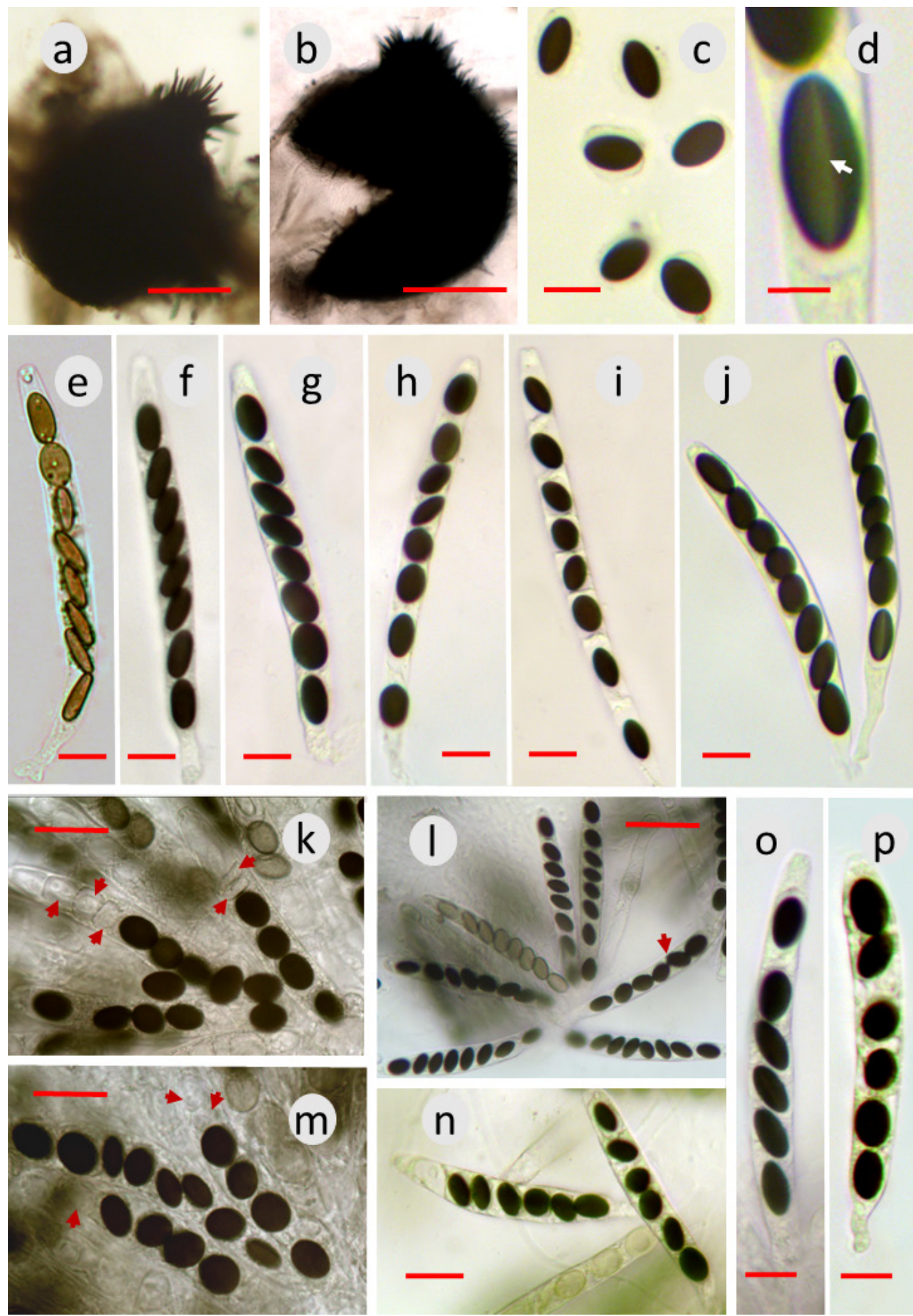

Fig. 2. Coniochaeta vagans (KW-M $50613 a, c, d, e-g$; KW-M70960 b, $h-j$; KW-M50643 l-p): $a, b-$ squashed ascomata; $c-$ free mature ascospores with gelatinous sheaths; $d$ - mature ascospore showing germ slit (arrow) $; e$-immature 8 -spored ascus; $f-j$ - mature 8 -spored asci; $k$ - asci contemporaneously containing both normally developed and abortive (arrows) spores; $l-8$-spored and 6-spored (arrow) asci; $m-8$-spored asci and 4-spored asci with abortive (arrows) spores; $n-p-6$-spored asci. Scale bars: $a, b-50 \mu \mathrm{m} ; c-j, o, p-15 \mu \mathrm{m} ; k, m-20 \mu \mathrm{m} ; l, n-30 \mu \mathrm{m}$ 
localities on various woody substrates (Fungi..., 1996; Dudka et al., 2004, 2009a).

Sordaria alcina N. Lundq., Symb. Bot. Upsal. 20(1): 326. 1972 (Fig. 3, $a-h$ ).

Description of Ukrainian collections. Ascomata perithecioid, aggregated, semi-immersed, dark brown to blackish, broadly ovoid to pyriform, 393-455 × 373$398 \mu \mathrm{m}$, glabrous or covered with sparse hyphoid hairs; neck conical or subcylindrical, black, 95-134 × 91$98 \mu \mathrm{m}$. Peridium membranaceous, thick, layered, with an exostratum made up of thick-walled, pale brown, angular to rounded cells. Asci eight-spored, cylindrical, $198.2-226.8 \times 14.2-15.9 \mu \mathrm{m}$, with a stipe measuring 18-21 $\mu \mathrm{m}$ long; unitunicate, slightly narrowed and flattened at the apex, with thickened apical ring, nonamyloid. Ascospores uniseriate, one-celled, smooth, thick-walled, olivaceous brown when young and dark brown when mature, narrowly ellipsoidal or sometimes cylindrical, pointed at the base, roundish at the apex, with a basal germ pore; (18.5-) 19.2-23.4 × (8.8-) 9.3-11.7 $\mu \mathrm{m}, \mathrm{Q}=1.8-2.3, \mathrm{Q}_{\mathrm{av}}=1.95$; gelatinous sheath hyaline, $2.5-4.7 \mu \mathrm{m}$ wide. Paraphyses abundant, hyaline, cylindric-moniliform, septate, soon collapsing.

Examined material. Kherson Region. Hola Prystan District, Black Sea Biosphere Reserve, Tendra Island, Bili Kuchuhury Cape, $46^{\circ} 14^{\prime}$ N, $31^{\circ} 38^{\prime}$ E, cow dung, 22 May 2007 (KW-M50615); Tendra Island, near "Austrian" lighthouse, steppe areas, $46^{\circ} 13^{\prime} \mathrm{N}, 31^{\circ} 47^{\prime} \mathrm{E}$, horse dung, 23 May 2007 (KW-M50610); Tendra Island, middle part, $46^{\circ} 13^{\prime} \mathrm{N}, 31^{\circ} 43^{\prime} \mathrm{E}$, horse dung, 23 May 2007 (KW-M50607), leg. V.P. Hayova, det. Yu.I. Lytvynenko. Sumy Region. Bilopillia District, Markivka village, grassland, $50^{\circ} 86^{\prime} \mathrm{N}, 34^{\circ} 38^{\prime} \mathrm{E}$, hare dung, 03 September 2013, leg./det. Yu.I. Lytvynenko.

General distribution. Europe: Finland, Italy, Latvia, Russia, Spain, Sweden, UK. Africa: Kenya. Australasia: Australia. North America: Canada.

Notes. Species of the Sordaria genus are known to have very similar morphological features, thus creating a challenge to species delimitation. According to Lundqvist (1972) and Guarro \& von Arx (1987), analysis of the perithecial structure, ascus and ascospore size is a very reliable way of delimiting Sordaria spp. At the same time, as Bell (2005) noted, numerous species of the genus "have overlapping ascospore sizes and in all other respects seem remarkably similar".

Sordaria alcina can be easily confused with morphologically resembling and widespread in Ukraine species, S. fimicola. According to various data, these species have distinct but overlapping dimensions of asci and ascospores. For $S$. fimicola, ascospore length and width vary within 19-27 × 11-15 $\mu \mathrm{m}$ (Cain, Groves, 1948); (17-) 18-24 × (9.5-) 11-13 $\mu \mathrm{m}$ (Lundqvist,

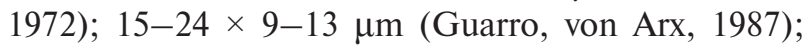
(15-) $17-24 \times 10-13 \mu \mathrm{m}$ (Doveri, 2004) and (19-) 20$25 \times 11-13 \mu \mathrm{m}$ (Bell, 2005). For $S$. alcina these values are reported as follows: $21-26 \times 9.5-12 \mu \mathrm{m}$ (Lundqvist, 1972; Doveri, 2004); 21-26.5 × 9.5-12 $\mu \mathrm{m}$ (Barrasa et al., 1986; Guarro, von Arx, 1987) and (19-)20-31 × 10-12 $\mu \mathrm{m}$ (Bell, 2005). As can be seen from the above, the two species differ in ascospore width which does not exceed $12 \mu \mathrm{m}$ in $S$. alcina. Correspondingly, a reliable diagnostic character to distinguish these species is the quotient $(\mathrm{Q})$ value, or length/width ratio. The latter for S. fimicola spores is varied within 1.4-1.7 (Guarro, von Arx, 1987; Doveri, 2004) while for S. alcina is always larger than 1.8 (Barrasa et al., 1986; Guarro, von Arx, 1987; Doveri, 2004). The quotient is in conformity with ascospore shape which can be used in delimiting species of this genus. Sordaria alcina was described by Lundqvist (1972) as having ellipsoidal or cylindrical ascospores (shown also in Fig. $3, b-h$ ) in contrast to broadly ellipsoidal or subglobose spores in other Sordaria species (for example, $S$. humana shown in Fig. $3, j-o$ ). This morphological distinction of $S$. alcina is consistent with a molecular phylogenetic analysis based on multiple gene sequences which clearly separated this species as distantly related to other sequenced Sordaria species (Cai et al., 2006).

Sordaria alcina is an obligate coprophilous fungus, currently known to occur exclusively on dung. Lundqvist (1972) described this species as apparently confined to cervid dung. Since then, it has been reported in feces of various animals, both domestic (cow, horse) and wild (deer, elk, hare, mouse). In Ukraine, S. alcina was found by now on dung of cow, horse and hare. These are the second published records of the species in the country, with a description and illustrations of the reported collections.

Sordaria humana (Fuckel) G. Winter, Bot. Zeit. 30: 835. 1872. E Sphaeria humana Fuckel, Fungi Rhenani Exsic. no.1801. 1866 (basyonym). = Sphaeria fermenti Fuckel Fungi Rhenani Exsic. no. 2165. 1868. $\equiv$ Hypocopra humana (Fuckel) Fuckel, Jb. nassau. Ver. Naturk. 23-24: 241. 1870. = Hypocopra fermenti (Fuckel) Fuckel, Jb. nassau. Ver. Naturk. 23-24: 241. 1870. $=$ Sordaria fermenti (Fuckel) G.Winter, Bot. Zeit. 30: 469. 1873. = Hypocopra fimeti (Pers.: Fr.) J.Kickx f. var. canina P.Karst., Bidr. Känn. Finl. Nat. Folk 23: 50. 1873. = Sordaria fimicola (Roberge) Ces. \& De Not. 

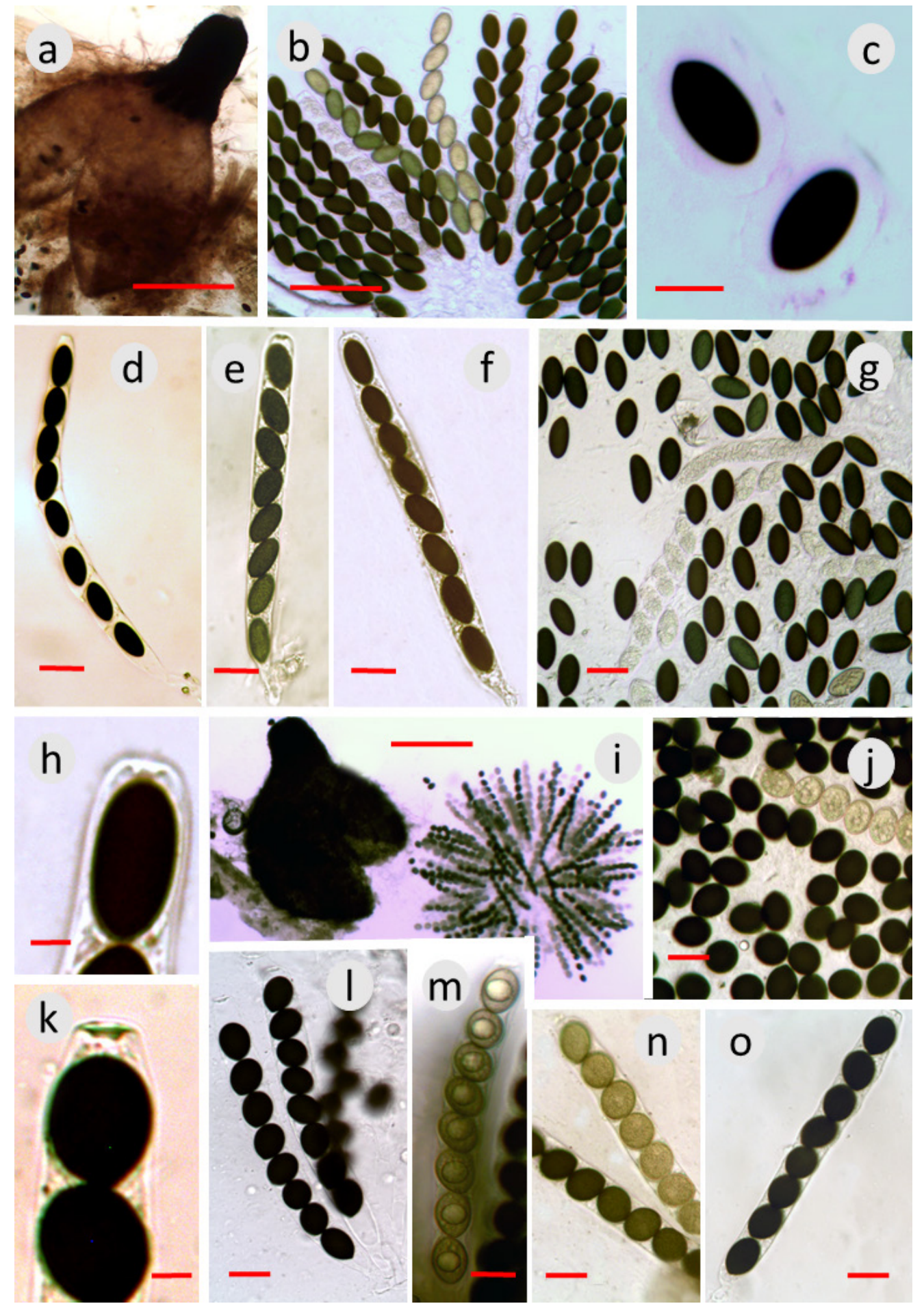

Fig. 3. Sordaria alcina (KW-M50610 $a, g$; KW-M50615 $b, c-f, h)$ : $a$ - squashed ascoma; $b$-details of the hymenium with 8 -spored mature and immature asci; $c$ - free mature ascospores whith gelatinous sheath; $d-f$ - mature asci with ascospores; $g$ - free mature ascospores; $h$ - ascus apex with apical apparatus. Sordaria humana $(\mathrm{KW}-\mathrm{M} 70957 k, j$; KW-M70956 $m-o): i-$ squashed ascoma; $j$ - free ascospores; $k$ - ascus apex with apical apparatus; $l, o$ - mature asci with ascospores; $m, n$ - immature asci with ascospores.

Scale bars: $a, i-200 \mu \mathrm{m} ; b-50 \mu \mathrm{m} ; c-10 \mu \mathrm{m} ; d-j, l-o-20 \mu \mathrm{m} ; h, k-5 \mu \mathrm{m}$

Укр. бот. журн., 2018, 75(6) 
var. canina (P.Karst.) E.S.Hansen, Vidensk. Meddel. Naturhist. Foren: 329. 1876. = Sordaria fermenti (Fuckel) G.Winter. var. phyllogena Sacc., Michelia 1(4): 373. 1878. = Coprolepa fimeti (Pers.: Fr.) Sacc. Syll. Fung. 1: 248. 1882. = Hypocopra phyllogena (Sacc.) Sacc., Syll. Fung. 1: 246. 1882. = Sordaria phyllogena (Sacc.) Niessl, Hedwigia 22: 155. 1883. = Sordaria fimicola (Roberge) Ces. \& De Not. var. humana (Fuckel) P.Karst., Acta. Soc. Fauna Fl. Fenn. 2(6): 79. 1885. = Sordaria wiesneri Zukal, Verh. K. K. Zool.-Bot. Ges. Wien 37: 41. 1887. = Sordaria sphaerospora Ellis \& Everh., North Amer. Pyrenom.: 128. 1892. = Hypocopra sphaerospora (Ellis \& Everh.) Sacc., Syll. Fung. 11: 280. 1895. = Pleurage fermenti (Fuckel) Kuntze, Rev. Gen. Plant 3(3): 505. 1898. = Pleurage humana (Fuckel) Kuntze, Rev. Gen. Plant 3(3): 505. 1898. = Pleurage wiesneri (Zukal) Kuntze, Rev. Gen. Plant. 3(3): 505. 1898. $\equiv$ Fimetaria humana (Fuckel) Griff. \& Seaver, North Amer. Fl. 3(1): 67. 1910. $\equiv$ Asordaria humana (Fuckel) Arx \& Guarro, Persoonia 13 (3): 268. 1987 (Fig. 3, i-o).

Description of Ukrainian collections. Ascomata perithecioid, aggregated, immersed or semi-immersed, dark brown to blackish, broadly ovoid to pyriform, $375-420 \times 290-335 \mu \mathrm{m}$, glabrous or soft-haired; neck blackish, short, conical or subcylindrical, 85-140 $\times$ 90-110 $\mu \mathrm{m}$. Peridium membranaceous, thick, layered, with an exostratum made up of thick-walled, brown, angular to rounded cells. Asci eight-spored, cylindrical, with a short stipe, 165.8-189.3 × 19.7-22.2 $\mu \mathrm{m}$; unitunicate, slightly narrowed and flattened at the apex, with thickened apical ring, non-amyloid. Ascospores uniseriate, one-celled, smooth, thick-walled, olivaceous brown when young and dark brown when mature, broadly ovoid (sometimes broadly ellipsoidal) to subglobose, pointed at the base, roundish at the apex, with a basal germ pore; $19.2-22.5 \times 14.9-17.0 \mu \mathrm{m}$, $\mathrm{Q}=1.13-1.48, \mathrm{Q}_{\mathrm{av}}=1.30$; gelatinous sheath narrow, ephemeral. Paraphyses hyaline, cylindric-moniliform, septate, soon reduced to a shapeless material.

Examined material. Sumy Region. Bilopillia District, Rudka village, private houses, $50^{\circ} 88^{\prime} \mathrm{N}, 34^{\circ} 43^{\prime} \mathrm{E}$, rabbit dung, 28 August 2013; Seredyna-Buda District, vicinity of Ulytsa village, Desniansko-Starohutsky National Nature Park, pine forest, quarter $76,52^{\circ} 32^{\prime} \mathrm{N}, 33^{\circ} 61^{\prime} \mathrm{E}$, hare dung, 20 September 2016 (KW-M70957); Sumy District, Stetskivka village, forest glade, $51^{\circ} 04^{\prime} \mathrm{N}$, $34^{\circ} 80^{\prime}$ E, roe deer dung, 26 February 2011; Nyzy settlement, Nyzy forestry, mixed forest, $50^{\circ} 41^{\prime} \mathrm{N}$, $34^{\circ} 52^{\prime}$ E, wild boar dung (soc. Sordaria fimicola
(Roberge ex Desm.) Ces. \& De Not.), 25 August 2015 (KW-M70956), leg./det. Yu.I. Lytvynenko.

General distribution. Europe: Austria, Bulgaria, Denmark, Estonia, Finland, France, Germany, Iceland, Italy, Latvia, Netherlands, Poland, Portugal, Russia, Spain, Sweden, Ukraine, UK. Africa: Kenya, Tanzania. Asia: Israel, Indonesia, Iraq, Uzbekistan, Japan. Australasia: Australia. North America: Canada, USA. South America: Argentina.

Notes. Sordaria humana is a cosmopolitan species growing on dung of omnivores (particularly man and dog), carnivores and herbivores, sometimes on seeds, soil, old paper and various decaying vegetable material. It is one of the most common fimicolous pyrenomycetes.

Morphologically $S$. humana is best characterized by its broadly obovoid to subglobose spores often lacking a gelatinous perisporium. However, it is unclear whether all known collections of this species lack gelatinous sheath. Some authors describe the spores devoid of perisporium (Minoura, 1969), while others report it to be present although variable in thickness (Boedijn, 1962; Liou, Chen, 1979; Khan, Krug, 1989) or ephemeral (Saccardo, 1882; Munk, 1957). Another point of view is that ascospores of $S$. humana lack gelatinous perisporium in collections only from carnivore dung (Lundqvist, 1972; Khan, Krug, 1989; Doveri, 2004). In this case, spores with or without a sheath may reflect substrate difference, since a sticky sheath would be ecologically determined for fungi on the dung of herbivores.

Von Arx et al. (1987) transferred S. humana and a few other species in a new genus, Asordaria, proposed for those species of Sordaria which possess ovoid or broadly ellipsoidal smooth ascospores surrounded by gelatinous sheath. However, these criteria were regarded not significant and thus separation of the taxa from Sordaria on that basis has been widely debated (Eriksson, Hawksworth, 1988; Khan, Krug, 1989). Thereafter, a multiple gene analyses conducted by Cai et al. (2006) provided evidence on the congeneric status of Asordaria and Sordaria.

We also regard this species within the genus Sordaria. Despite a wide distribution of S. humana, the examined materials represent the second published records of the species in Ukraine, with a description and illustrations of the reported collections.

Sordaria minima Sacc. \& Speg., Michelia 1(4): 373. 1878. $\equiv$ Hypocopra minima (Sacc. \& Speg.) Sacc., Syll. Fung. 1: 244. 1882 (Fig. 4). 

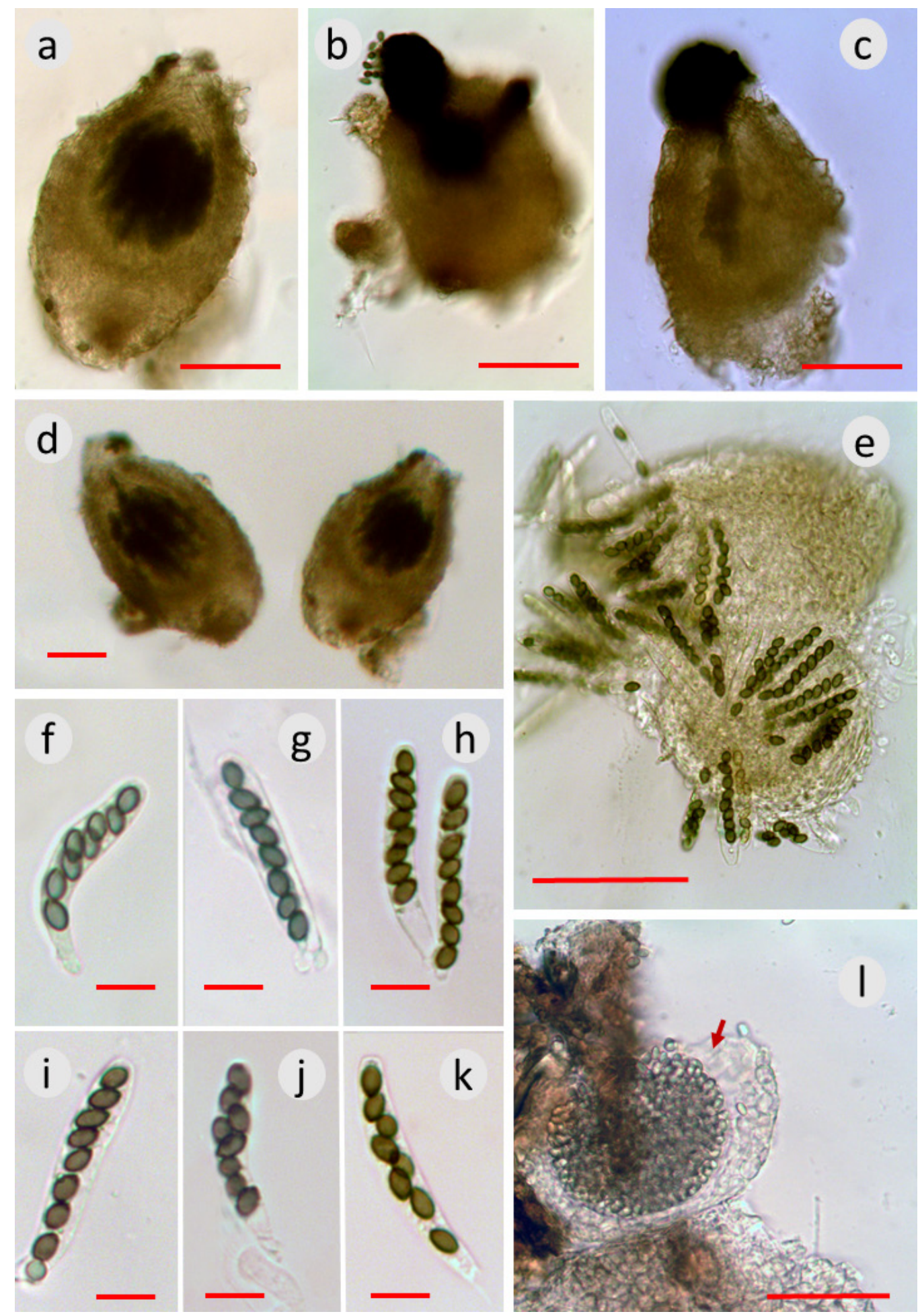

Fig. 4. Sordaria minima (KW-M70959 $a-f, i, l$; KW-M70958 $g, h, j, k$ ): $a-d-$ mounted ascomata, $e$ - squashed ascoma, $f-k$ - mature asci with ascospores, $l$ - ruptured apothecium of Theleobolus cf. stercoreus with a single ascus containing multiple ascospores (arrow), associated with ascoma of S. minima.

Scale bars: $a-e-50 \mu \mathrm{m} ; f-k-10 \mu \mathrm{m} ; l-100 \mu \mathrm{m}$

Укр. бот. журн., 2018, 75(6) 
Description of Ukrainian collection. Ascomata perithecioid, scattered, semi-immersed, pale brown, broadly ovoid to pyriform, 127-163 × 91$105 \mu \mathrm{m}$, glabrous; neck dark brown, short, conical or subcylindrical, $35-52 \times 43-58 \mu \mathrm{m}$. Peridium membranaceous, thin, layered, consists of pale brown to colorless, thin-walled rounded cells, translucent so that asci and coloured spores can be seen through the peridium. Asci eight-spored, cylindrical or cylindricalclavate, with a short stipe, 35.6-46.4 × 7.2-8.7 $\mu \mathrm{m}$; unitunicate, rounded or slightly flattened at the apex, without apical ring, non-amyloid. Ascospores mostly uniseriate, one-celled, smooth, thick-walled, olivaceous brown when young and dark brown when mature, broadly ellipsoidal, with an apical germ pore; $5.13-6.53 \times 3.54-4.06 \mu \mathrm{m}, \mathrm{Q}=1.36-1.72, \mathrm{Q}_{\mathrm{av}}=1.54$; lacking a gelatinous sheath. No true paraphyses seen.

Examined material. Sumy Region, Sumy District, Nyzy settlement, Nyzy forestry, mixed forest, $50^{\circ} 41^{\prime} \mathrm{N}$, 34.52' E, roe deer dung (soc. Arnium cervinum N. Lundq.), 03 August 2015 (KW-M70958); forest glade, $50^{\circ} 41^{\prime}$ N, 345' E, roe deer dung (soc. Saccobolus aff. verrucisporus Brumm.), 25 August 2015 (KW-M70959), leg./det. Yu.I. Lytvynenko.

General distribution. Europe: Denmark, Germany, Iceland, Italy, Netherlands, Sweden, Ukraine, UK. North America: USA. South America: Argentina.

Notes. This is a very interesting and rare fungus. Nomenclature, identity and placement of this taxon remain problematic. It is referred to in the literature as "Sordaria minima problem" (Doveri, 2004). Since its original description by Saccardo (1878), the species has been variously interpreted. In this article we use the name $S$. minima Sacc. \& Speg. because it is currently listed as an accepted name both in Index Fungorum (http://www.indexfungorum.org/, accessed 17.10.2018) and Mycobank (http://www.mycobank. org/, accessed 17.10.2018) online databases. However, morphological characters of our specimens fit better the descriptions provided for this fungus by Massee \& Salmon (1901), Larsen (1971), Richardson (1998) and Doveri (2004) rather than its protologue. The last three authors suggested that the fungus was misplaced within Sordaria, due to schizothecioid, i.e. nonsordariaceous, structure of the peridium, asci lacking an apical apparatus and spores without a gelatinous sheath. Formerly it was proposed to consider this species name as nomen ambiguum (Moreau, 1953) or nomen dubium (Larsen, 1971). Moreover, according to Lundqvist's comments on the unusual combination of morphological characters, Doveri (2004) stated that the species should be re-classified and regarded within either Chaetomiaceae or Ceratostomataceae, but not Sordariaceae. It is obvious that in order to clarify the taxonomic status and placement of this fungus, further morphological and particularly molecular studies are required.

In our specimens, perithecia are schizothecioid in structure (Fig. 4, $a-d$ ), with thin translucent walls composed of hyaline to smoky-hyaline cells (Fig. 4,e). Asci have no distinct apical structure; ascospores without a gelatinous sheath or appendages but with a germ pore at one end; ascospores mostly uniseriate, rarely obliquely uniseriate or overlapping in the middle part of the ascus (Fig. $4, f-k$ ). In general, all features we observed fit those in descriptions of the collections from the UK (Massee, Salmon, 1901; Richardson, 1998), Denmark (Larsen, 1971), and Italy (Doveri, 2004), with one exception. Larsen (1971) reported 4-spored asci in some perithecia in her collections, and rarely both 8-spored and 4-spored asci in the same perithecia. We have not observed 4-spored asci in our specimens.

Sordaria minima was reported on dung of various animals, mostly herbivorous, and a bird: cow, rabbit, hare, horse, goat, fallow deer and red grouse (Spegazzini, 1899; Saccardo, 1882; Massee, Salmon, 1901, Larsen, 1971; Lundqvist, 1972; Richardson, 1998). It is a rare fungus in Europe, recorded in each country from a single or a few localities. Massee and Salmon (1901) and Richardson $(1998,2004)$ admit that due to small perithecia it can be also overlooked.

Regarding the ecological role of this fungus, it has been revealed that being a coprophile, S. minima shows the ability to act as a mycoparasite. Doveri (2004) following Lundquist's comment on the habitat of $S$. minima cited that "the fungus grows sometimes directly on dung, but its mycelium is then probably in contact with the discomycetes". He concluded that S. minima is obviously a parasite of Thelebolus sp. In one of our specimens, an apothecium of Thelebolus cf. stercoreus Tode (Fig. 4, $l$ ) was also found in immediate proximity to perithecia of $S$. minima. We regard it as evidence to confirm that $S$. minima has ability to parasitize a saprobic fungus on dung.

Our records of $S$. minima are the first for Ukraine, as well as for Eastern Europe.

\section{Acknowledgements}

The authors acknowledge technical assistance by N.S. Novichenko, a staff member of the M.G. Kholodny Institute of Botany, NAS of Ukraine, in scanning electron microscopy. 


\section{REFERENCES}

Akulov O.Yu., Golubtsova Yu.I., Mikos I.G., Dyakova I.V. Micromycetes of Kremenetski Hory National Nature Park and adjacent areas. In: Pryrodno-zapovidny fond Ukrainy - mynule, syohodennia, maybutne. Ternopil: Pidruchnyky i posibnyky, 2010, pp. 201-206 [Акулов О.Ю., Голубцова Ю.І., Мікос І.Г., Дьяконова І.В. Мікроміцети Національного природного парку "Кременецькі гори" та навколишніх територій. В кн.: Природно-заповідний фонд України - минуле, сьогодення, майбутнє: Зб. наук. статей, присвяч. 20-річчю від дня заснування природного заповідника "Медобори". Тернопіль: Підручники і посібники, 2010, c. 201-206].

Arx von J.A., Guarro J., van der Aa H.A. Asordaria, a new genus of the Sordariaceae, and a new species of Melanocarpus. Persoonia, 1987, 13(3): 263-272.

Asgari B., Zare R., Gams W. Coniochaeta ershadii, a new species from Iran, and a key to well documented Coniochaeta species. Nova Hedwigia, 2007, 84(1-2): 175-187.

Barrasa J.M., Lundquist N., Moreno G. Notes on the genus Sordaria in Spain. Persoonia, 1986, 13(1): 83-88.

Bell A. An illustrated guide to the coprophilous Ascomycetes of Australia. CBS, Centraalbureau voor Schimmelcultures, Utrecht, The Netherlands, 2005, 172 pp.

Bobyak G. Zbirnyk matematychno-pryrodopysno-likarskoyi sektsiyi nauk. t-va im. Shevchenka, 1907, 11: 1-41. [Боб'як Г. Причинки до мікольогії східної Галичини. Гриби околиць Бережан. Збірник математично-природописно-лікарської секції наук. тов-ва ім. Шевченка, 1907, 11: 1-41].

Boedijn K.B. The Sordariaceae of Indonesia. Persoonia, 1962, 2(3): 305-320.

Cai L., Jeewon R., Hyde K.D. Phylogenetic investigations of Sordariaceae based on multiple gene sequences and morphology. Mycol. Res., 2006, 110(2): 137-150. https://doi. org/10.1016/j.mycres.2005.09.014

Cain R.F. Studies of coprophilous Sphaeriales in Ontario. Univ. of Toronto Studies. Biol. Ser., 1934, 38: 1-126.

Cain R.F., Groves J.W. Notes on seed-borne fungi VI. Sordaria. Canad. J. Res., 1948, 26(5): 486-495. https://doi. org/10.1139/cjr48c-032

Chang J.-H., Wang Y.-Z. Taxonomy of Coniochaeta leucoplaca and $C$. velutina: morphological and molecular studies based on LSU rDNA of isolates from Taiwan. Nova Hedwigia, 2011, 92: 57-67. https://doi. org/10.1127/0029-5035/2011/0092-0057

Checa J., Barrasa J.M., Moreno G., Fort F., Guarro J. The genus Coniochaeta (Sacc.) Cooke (Coniochaetaceae, Ascomycotina) in Spain. Cryptogamie Mycologie, 1988, 9(1): $1-34$.

Doveri F. Fungi fimicoli Italici. A guide to the recognition of Basidiomycetes and Ascomycetes living on faecal material. Trento: Assoc. Micol. Bresadola, 2004, 1104 pp.

Dudka I.O., Heluta V.P., Tykhonenko Yu.Ya., Andrianova T.V., Hayova V.P., Prydiuk M.P., Dzhagan V.V., Isikov V.P. Fungi of the Crimean peninsula. Kyiv: Fitosotsiotsentr, 2004, 452 pр. [Дудка I.О., Гелюта В.П.,
Тихоненко Ю.Я., Андріанова Т.В., Гайова В.П., Придюк М.П., Джаган В.В., Ісіков В.П. Гриби природних зон Криму. Київ: Фітосоціоцентр, 2004, 452 c.].

Dudka I.O., Heluta, V.P., Andrianova T.V., Hayova, V.P., Tykhonenko Yu.Ya., Prydyuk M.P., Golubtsova Yu.I., Kryvomaz T.I., Dzhagan V.V., Leontyev D.V., Akulov O.Yu., Syvokon O.V. Fungi of nature reserves and national nature parks of Eastern Ukraine. Kyiv: Aristey, 2009a, vol. 2, 428 pp. [Дудка I.О., Гелюта, В.П., Андріанова Т.В., Гайова, В.П., Тихоненко Ю.Я., Придюк М.П., Голубцова Ю.І., Кривомаз Т.І., Джаган В.В., Леонтьєв Д.В., Акулов О.Ю., Сивоконь О.В. Гриби заповідників та національних природних парків Лівобережної України. Київ: Арістей, 2009а, т. 2, 428 c.].

Dudka I.O., Prydiuk M.P., Golubtsova Yu.I., Andrianova T.V., Karpenko K.K. Fungi and fungus-like organisms of Desniansko-Starohutsky National Nature Park. Sumy: Universitet. knyha, 2009b, 223 pp. [Дудка I.O., Придюк М.П., Голубцова Ю.І., Андріанова Т.В., Карпенко К.К. Гриби та грибоподібні організми національного природного парку "ДеснянськоСтарогутський". Суми: Університет. книга, 2009b, 223 c.].

Dzhagan V.V., Prudenko M.M., Heluta V.P. Fungi of Kaniv Nature Reserve. Kyiv: Kyiv University Press, 2008, 271 pp. [Джаган В.В., Пруденко М.М., Гелюта В.П. Гриби Канівського природного заповідника. Київ: Вид-во Київ. ун-ту, 2008, 271 с.].

Eriksson O.E., Hawksworth D.L. Notes on ascomycete systematics. Systema Ascomycetum, 1988, 7(1): 59-101.

Fakirova V. Surveys on coprophilous Ascomycetes in Bulgaria. III. Izv. Bot. Inst. (Sofia), 1969, 19: 199-210. [Факирова В. Проучвания върху копрофилните Ascomycetes в България. III. Изв. на Ботан. инст., 1969, 19: 199-210].

Fungi of Ukraine: A Preliminary Checklist. Eds D.W. Minter, I.O. Dudka. CAB International, M.G. Kholodny Institute of Botany, 1996, $361 \mathrm{pp}$.

Golubtsova Yu.I. Ukr. Bot. J., 2008, 65(5): 701-710. [Голубцова Ю.І. Нові для України види копрофільних аскоміцетів. I. Піреноміцети та локулоаскоміцети. Укр. бот. жмурн., 2008, 65(5): 701-710].

Golubtsova Yu.I., Mikos I.G., Akulov O.Yu. New records of coprophilous Ascomycetes in the Crimea. Chornomors'k. bot. z., 2010, 6(1): 67-83. [Голубцова Ю.І., Мікос І.Г., Акулов О.Ю. Нові знахідки копрофільних аскоміцетів з Криму. Чорноморськ. бот. жс., 2010, 6(1): 67-83].

Guarro J., Arx von J.A. The ascomycete genus Sordaria. Persoonia, 1987, 13(3): 301-313.

Hawksworth D.L., Yip H.Y. Coniochaeta angustispora sp. nov. from roots in Australia, with a key to the species known in culture. Austral. J. Bot., 1981, 29(3): 377-384.

Hayova V.P. In: Zbirnyk nauk. prats Luhanskoho Nats. Ahrarnoho Univ., 2005, 56(79): 117-129. [Гайова В.П. Аскоміцети Луганського природного заповідника (крім порядку Erysiphales). Збірник наук. праць 
Луганськ. нац. аграр. ун-ту. Сер. Біол. науки, 2005, 56(79): 117-129].

Heine N., Welt P. Beiträge zur Kenntnis coprophiler Pilze (4). Coprophile Pilze im Hartschimmelgebiet bei Andechs und weitere bayerische Dungpilzfunde. Mycologia Bavarica, 2008, 10: 63-83.

Khan R.S., Krug J.C. New records of the Sordariaceae from the East Africa. Mycologia, 1989, 81(6): 862-869. https://doi.org/10.2307/3760104

Kirk P.M., Cannon P.F., David J.F., Minter D.W., Stalpers J.A. Ainsworth \& Bisby's Dictionary of the Fungi, $10^{\text {th }}$ ed. Wallingford: CAB Intern., 2008, $771 \mathrm{pp}$.

Krupa J. Zapiski mycologiczne z okolic Lwowa i z Podtatrza. Sprawozdanie Komisyji Fizyograficzney (Sprawozdanie Komisyi Fizyograficznej), 1888, 22(2): 12-47.

Larsen K. Danish endocoprophilous fungi, and their sequence of occurrence. Botanisk Tidsskrift, 1971, 66 $(1-2): 1-32$.

Liou S.-C., Chen Z.-C. Preliminary studies on coprophilous Pyrenomycetes from Taiwan. Taiwania, 1979, 24: 11-21.

Lundquist N. Nordic Sordariaceae s. lat. Symbolae Botanicae Upsalienses, 1972, 20(1): 1-374.

LytvynenkoYu.I., Stepanovska N.V.Pryrodnychinauky, 2014, 11: 17-23. [Литвиненко Ю.І., Степановська Н.В. Копрофільні аскоміцети долини р. Сула в межах Білопільського району Сумської області. Природничі науки, 2014, 11: 17-23].

Mahoney D.P., LaFavre J.S. Coniochaeta extramundana, with a synopsis of other Coniochaeta species. Mycology, 1981, 73(5): 931-952.

Massee G., Salmon E.S. Researches on coprophilous fungi. Annals of Botany, 1901, 15(58): 313-357.

Milovtsova M.O. Trudy NDI botaniky pry Kharkiv. dezh. univ., 1937, 2: 17-22. [Міловцова М.О. Матеріали до мікофлори УРСР. Труди НДІ ботаніки при Харків. держ. ун-ті, 1937, 2: 17-22].

Minoura K. Notes of some Ascomycetes of East Africa. Transactions of the Mycol. Soc. of Japan, 1969, 10(2): 41-46.

Munk A. Danish Pyrenomycetes: a preliminary flora. Dansk Botanik Arkiv, 1957, 17: 1-491.

Moravec Z. Remarks on some coprophilous fungi in Norway. Czech Mycology, 1968, 22(4): 301-309.

Moreau C. Les genres Sordaria et Pleurage. Encycl. mycol., 1953, 25: 48-136.

Namysłowski B. Przyczynek do mykologii Galicyi. Sprawozdanie Komisji Fizjograficzney, 1910, 44(3): 43-48.
Namysłowski B. Śluzowce i grzyby Galicyi i Bukowiny. Pamętnik Fizyograficzny, 1914, 22(4): 1-151.

Prokhorov V.P., Armenskaya N.L. Bull. MOIP, 2001, 106(2): 78-82. [Прохоров В.П., Арменская Н.Л. Копротрофные перитециоидные аскомицеты европейской части России. Бюл. МОИП, 2001, 106(2): 78-82].

Prokhorov V.P., Armenskaya N.L. Vestnik MGU. Ser. Biologia, 2003, 16: 47-52. [Прохоров В.П., Арменская Н.Л. Род Sordaria в России и некоторых сопредельных странах. Вестн. МГУ. Сер. Биология, 2003, 16: 47-52].

Richardson M.J. New and interesting records of coprophilous fungi. Bot. J. Scotland, 1998, 50(2): 161-175. https://doi.org/10.1080/03746609808684913

Richardson M.J. Coprophilous fungi from Iceland. Acta Botanica Islandica, 2004, 14: 77-103

Saccardo P.A. Fungi Veneti novi vel critici vel mycologiae Venetae addendi. Ser. 9. Michelia, 1878, 1(4): 361-445.

Saccardo P.A. Sylloge Fungorum Omnium Hucusque Cognitorum. Vol. 1. Sylloge Pyrenomycetum omnium hucusque cognitorum, 1882, xix +768 pp.

Smitskaya M.F., Smyk L.V., Merezhko T.A. Handbook of pyrenomycetes of the USSR. Kiev: Naukova Dumka, 1986, 364 рр. [Смицкая М.Ф., Смык Л.В., Мережко Т.А. Определитель пиреномицетов УССР. Киев: Наук. думка, 1986, 364 с.].

Spegazzini C. Fungi Argentini Novi v. critici. Anales del Museo Nacional de Buenos Aires, 1899, 6(2, 3): 81-365.

Shlakhter M.L. In: Materialy XI Mizhnarodnoi naukovoi konferentsii molodykh naukovtsiv "Biolohiya: vid molekuly do biosfery" (26 lystopada - 2 hrudnya 2016 r., Kharkiv, Ukraina). Kharkiv: Vyd-vo Khark. univ., 2016, p. 164. [Шлахтер М.Л. Перші відомості про копрофільні гриби Національного природного парку "Дністровський каньйон". У зб.: Матеріали XI Міжнародної наукової конференції молодих науковців "Біологія: від молекули до біосфери" (26 листопада - 2 грудня 2016 р., Харків, Україна). Харків: Вид-во Харк. ун-ту, 2016, с. 164].

Taylor L.D. Coniochaeta velutina and its synonyms. Canad. J. Bot., 1970, 48(1): 81-83.

Watling R., Richardson M.J. Coprophilous fungi of the Falkland Islands. Edinburgh J. Bot., 2010, 67(3): 399423. http://doi.org/10.1017/S0960428610000156

Recommended for publication by

Submitted 01.08.2018 V.P. Heluta 
Литвиненко Ю.І. ${ }^{1}$, Гайова В.П. ${ }^{2}$ Нові та цікаві знахідки копрофільних видів родів Coniochaeta i Sordaria (Sordariomycetes, Ascomycota) в Україні. Укр. бот. журн., 2018, 75(6): 538-551.

${ }^{1}$ Сумський державний педагогічний університет імені А.С. Макаренка вул. Роменська, 87, Суми 40002, Україна

${ }^{2}$ Інститут ботаніки ім. М.Г. Холодного НАН України вул. Терещенківська, 2, Київ 01004, Україна

У статті представлені нові дані про поширення п'яти копрофільних видів родів Coniochaeta і Sordaria в Україні. Ці гриби є представниками великої групи копрофільних видів, що належать до класу Sordariomycetes. На відміну від копрофільних дискоміцетів, ця група грибів $€$ маловивченою в Україні. Зразки відповідних субстратів були зібрані на о-ві Тендра в Чорному морі (Херсонська обл.) та на північному сході країни (Сумська обл.). Всі досліджені зразки були отримані шляхом інкубації у вологих камерах. У статті повідомляється про три нові для України види: Coniochaeta leucoplaca, C. vagans та Sordaria minima; останній вперше зареєстрований у Східній Европі. Ше для двох видів - Sordaria alcina та S. humana це друге повідомлення про знахідку на території країни. Для всіх видів наведено описи українських зразків на різних типах субстрату й порівняння 3 оригінальними описами видів. На основі зібраних зразків детально описані характерні морфологічні ознаки кожного виду. Всі види проілюстровано мікрофотографіями, отриманими з використанням світлової та скануючої електронної мікроскопії. Для кожного зразка наводиться локалітет, субстрат і дата збору. Стисло обговорено екологічні особливості та загальне поширення цих видів.

Ключові слова: Coniochaeta leucoplaca, Coniochaeta vagans, Sordaria alcina, Sordaria humana, Sordaria minima, копрофільні гриби, екскременти, поширення
Литвиненко Ю.И. ${ }^{1}$, Гаевая В.П. ${ }^{2}$ Новые и интересные находки копрофильных видов родов Coniochaeta и Sordaria (Sordariomycetes, Ascomycota) в Украине. Укр. бот. журн., 2018, 75(6): 538-551.

${ }^{1}$ Сумской государственный педагогический университет имени А.С. Макаренко

ул. Роменская, 87, Сумы 40002, Украина

${ }^{2}$ Институт ботаники им. Н.Г. Холодного НАН Украины ул. Терешенковская, 2, Киев 01004, Украина

В статье представлены новые данные о распространении пяти копрофильних видов родов Coniochaeta и Sordaria в Украине. Эти грибы являются представителями большой группы копрофильних видов, принадлежащих к классу Sordariomycetes. В отличие от копрофильних дискомицетов, эта группа грибов является малоизученной в Украине. Образцы соответствующих субстратов были собраны на о-ве Тендра в Черном море (Херсонская обл.) и на северо-востоке страны (Сумская обл.). Все исследованные образцы были получены путем инкубации во влажных камерах. В статье сообщается о трех новых для Украины видах: Coniochaeta leucoplaca, C. vagans и Sordaria minima; последний вид впервые зарегистрирован в Восточной Европе. Для двух других видов - Sordaria alcina и $S$. humana - это второе сообщение о находке на территории страны. Для всех видов приведены описания украинских образцов на различных типах субстрата и сравнения с оригинальными описаниями видов. На основе собранных образцов подробно описаны характерные морфологические признаки каждого вида. Все виды проиллюстрированы микрофотографиями, полученными с использованием световой и сканирующей электронной микроскопии. Для каждого образца приводится локалитет, субстрат и дата сбора. Кратко обсуждаются экологические особенности и общее распространение данных видов.

Ключевые слова: Coniochaeta leucoplaca, Coniochaeta vagans, Sordaria alcina, Sordaria humana, Sordaria minima, копрофильные грибы, екскременты, распространение 